Kovalchuk, Z., Raievska, Y., Beheza, L., Ievtushenko, I., \& Odyntsova, H. (2021). Socio-psychological features and legal norms of the life of adolescents from distant families of labor migrants. Amazonia Investiga, 10(46), 79-91. https://doi.org/10.34069/AI/2021.46.10.7

\title{
Socio-psychological features and legal norms of the life of adolescents from distant families of labor migrants
}

\section{СОЦІАЛЬО-ПСИХОЛОГІЧНІ ОСОБЛИВОСТІ ТА ПРАВОВІ НОРМИ ЖИТТЕДІЯЛЬНОСТІ ПІДЛІТКІВ ІЗ ДИСТАНТНИХ СІМЕЙ ТРУДОВИХ МIГРАНТIB}

\author{
Received: July 20, $2021 \quad$ Accepted: September 23, 2021 \\ Written by: \\ Zoriana Kovalchuk ${ }^{21}$ \\ https://orcid.org/0000-0002-2355-2129 \\ Yana Raievska ${ }^{22}$ \\ https://orcid.org/0000-0003-3802-2304 \\ Web of Science Researcher ID C-8527-2019 \\ Scopus: https://www.scopus.com/authid/detail.uri?authorId=57218830781 \\ Liudmila Beheza ${ }^{23}$ \\ https://orcid.org/0000-0002-5361-4677 \\ Iryna Ievtushenko ${ }^{24}$ \\ https://orcid.org/0000-0001-5145-7332 \\ Halyna Odyntsova ${ }^{25}$ \\ https://orcid.org/0000-0002-7102-7724
}

\begin{abstract}
The article considers the distant family as a social institution of education, formation and development of personality. The current state of solving the problem of socio-psychological and legal work with children from distant families is analyzed.

The sample of the study is described in detail by family type, sex, absence of father / mother and duration of absence. The peculiarities of the functioning of the emotional sphere of adolescents from distant families (anxiety, aggression, hostility), low level of sociopsychological adaptation, low level of emotional well-being in the family have been experimentally determined. The relationship between the degree of socio-psychological adaptation of the adolescent's personality and emotional states is proved. The dependence of gender differences in the functioning of the
\end{abstract}

\begin{abstract}
Анотація
У статті розглядається дистантна сім'я як соціальний інститут виховання, формування і розвитку особистості. Проаналізовано сучасний стан вирішення проблеми соціальнопсихологічної та правової роботи 3 дітьми 3 дистантних сімей. Розкрито особливості становлення особистості підлітків 3 дистантних сімей.

Детально описано вибірку дослідження за типом сім'ї, статтю, за відсутністю батька/матері та за тривалістю відсутності. Експериментально визначені особливості функціонування емоційної сфери підлітків 3 дистантних сімей (тривожність, агресивність, ворожість), низький рівень соціальнопсихологічної адаптації, низький рівень емоційного благополуччя в родині. Доведено взаємозв'язок між ступенем соціальнопсихологічної адаптованості особистості підлітка й емоційними станами. Встановлено
\end{abstract}

\footnotetext{
${ }^{21}$ Doctor of psychological sciences, Associate Professor, Head of the Theoretical Psychology department, Institute of Management, Psychology and Security, Lviv State University of internal affairs, Lviv, Ukraine.

${ }^{22}$ Doctor of Psychology, Professor, Department of Psychology, Ukrainian State Employment Service Training Institute, Kyiv, Ukraine.

${ }^{23}$ Doctor of Psychology, Professor, Department of Psychology, Ukrainian State Employment Service Training Institute, Kyiv, Ukraine.

${ }^{24} \mathrm{PhD}$ in Psychology, Associate Professor, Associate Professor, Department of Psychology, Ukrainian State Employment Service Training Institute, Kyiv, Ukraine.

${ }^{25}$ Candidate of Psychological Sciences, Head of the Practical Psychology Department, Institute of Management, Psychology and Security, Lviv State University of Internal Affairs, Lviv, Ukraine.
} 
family and the emotional sphere of adolescents has been established. The types of groups of adolescents from distant families are determined, in particular: anxious, aggressive-anxious, hostile-anxious, aggressive-hostile, absence of manifestation of negative signs.

A structural and functional model of social and psychological support of remote families has been developed, which provides for work with adolescents and their parents with the use of special technologies to ensure the effectiveness of conditions that form harmonious family relationships.

Keywords: socio-psychological features, legal norms, distant family, emotional sphere, psychotherapy, psychological consultancy.

\section{Introduction}

In the context of modern educational and legal priorities, attention remains to the problem of the existence of a social phenomenon in our country - distant families of migrant workers, social development and mental development of children in these families. Undoubtedly, the educational potential of parents acquires great importance in the upbringing of the younger generation, the formation of the adolescent's personality, because the family is the most important institution of socialization and education, in which children acquire the first залежність гендерних відмінностей функціонування сім'ї та емоційної сфери підлітків. На підвищений рівень тривожності підлітків впливає відсутність матері протягом від одного до трьох років, на підвищений рівень тривожності у дівчат - відсутність матері на термін до одного року; підвищений рівень агресивності, реакції на фрустрацію, дезадаптованості виявився у підлітків при відсутності матері в сім’ї на термін від одного до трьох років, на рівень сімейних відносин впливає відсутність матері в сім'ї тривалістю до одного року на дівчат і відсутність матері в будинку протягом одного-трьох років на підлітків в цілому. Визначено типи груп підлітків 3 дистантних сімей, зокрема: тривожні, агресивно-тривожні, ворожо-тривожні, агресивно-ворожі, відсутність прояви негативних ознак.

В результаті аналізу змін емоційної сфери підлітків 3 дистантних сімей основна увага приділяється умовам соціально-психологічного супроводу дистанційних сімей. Розроблено структурно-функціональну модель соціальнопсихологічного супроводу дистанційних сімей, яка передбачає роботу 3 підлітками та їх батьками 3 застосуванням спеціальних технологій для забезпечення дієвості умов, що формують гармонійні сімейні стосунки.

Програма корекції, створена на основі вищезгаданої моделі, в ході апробації дозволила знизити рівень емоційної напруги. Виявлена позитивна динаміка емоційної сфери підлітків, а саме: зниження рівня тривожності, агресивності, ворожості, підвищення рівня соціально-психологічної адаптованості і поліпшення стану здоров'я та емоційного благополуччя в родині.

Ключові слова: соціально-психологічні особливості, правові норми, дистантна сім'я, життедіяльність, сімейне виховання, сімейні міжособистісні стосунки, підлітки, емоційна сфера, тривожність, агресивність, реакція на фрустрацію, соціально-психологічна адаптація, соціально-психологічний супровід, корекція, психотерапія, психологічне консультування.

skills of interaction, learn the first social roles, reflect norms and values parents influences the formation of the child's first and most stable "self-image", and then adequate self-esteem and a branched and harmonious I-concept. The general scientific and psychological constant was the recognition that the main factors of family life are: the emotional unity of the child with his parents; emotional relationships between family members; atmosphere of security, desirability, love. However, for modern families, due to objective and subjective reasons, there is a lack 


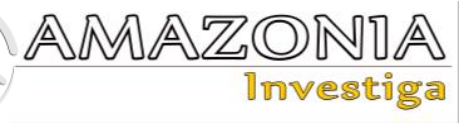

of direct communication between parents and children in the family circle.

Thus, the problem of the disintegrating influence of labor migration on the formation of the child's personality in a distant family is quite relevant and requires further in-depth study and public attention. In our opinion, the Ministry of Education and Science of Ukraine, the Ministry of Family, Youth and Sports of Ukraine, the Ministry of Labor and Social Policy, the Ministry of Health, the Ministry of Affairs, the Ministry of Justice of Ukraine and others are obliged to take care of these issues directly.

\section{Theoretical Framework or Literature Review}

The issues of proper upbringing of children, reaching an understanding between parents and children, the responsibility of parents for improper performance of parental responsibilities are always important and relevant. The Law of Ukraine "On Child Protection" stipulates that parents or persons replacing them are obliged to raise a child, take care of his health, physical, spiritual and moral development, education, create appropriate conditions for the development of his natural abilities, respect dignity of the child, to prepare him for independent living and work. The law stipulates that family upbringing is the primary basis for the development of a child's personality. The responsibility for the upbringing of children lies with both parents, whether they live together or separately, as the responsibility for the proper upbringing and care of the minor is equal for both of them.

Responsibility, as a feature of human character, formed in the process of joint activities, is the result of the internalization of social values, norms, rules, inherent only in the mature individual. The responsibility of the individual to society is characterized by conscious observance of moral principles and legal norms. The responsible personality has the following traits: hyper social attitudes, altruism, sincerity, obligation, obligation, willingness to help others, organization, diligence, diligence, concentration, resilience, awareness, etc.

In line with the study of the problem of civil and family liability of parents for offenses committed by minors, M. Logvinova (2009) drew attention to defining the essence of the concept of "parental responsibility for minors": "the offender in case of non-compliance with the requirements of the law (terms of the contract, court decision), as a result of which he is deprived or restricted of personal non-property or property rights, which helps to protect the violation of subjective rights and interests".

Bringing parents to family responsibility is a means of protecting the child's right to proper upbringing in a family environment.

The state provides protection of the family and childhood by defining the rights, duties and responsibilities of persons who have certain family relations or carry out educational, educational and other activities related to children and adolescents. These are: laws, regulations, decrees, programs, etc. Among the main documents in force in our country are the following: the Convention on the Rights of the Child, the Constitution of Ukraine, the Family Code of Ukraine, the Laws of Ukraine "On Child Protection", "On Education", "On Preschool Education”, "On General Secondary Education”, "On extracurricular education", "On promoting social formation and development of youth in Ukraine", "On social work with children and youth", "On youth and children's public organizations", "On state assistance to families with children", "On prevention of domestic violence", "Fundamentals of Ukrainian legislation on health care", National Program "Children of Ukraine", Resolution of the Verkhovna Rada of Ukraine "On the Concept of State Family Policy", Decree of the President of Ukraine "On additional measures to strengthen social protection of large and single-parent families", Resolution of the Cabinet of Ministers of Ukraine "On approval of the Regulations on foster care", Presidential Decree "On the Standard Regulations on Asylum for Minors", etc.

The implementation of the state family policy is carried out by ensuring the regulatory framework in general and in certain areas of life in particular. Among them: norms of family law, marital responsibility, and parental responsibility.

Investigating the peculiarities of state regulation of the family institution in Ukraine, researcher L. Melnychuk (2019) notes that the process of formation of the social institution of the family is characterized by the presence of destructive phenomena and problems, including: low level of satisfaction of individual interests and needs, related to the creation and functioning of a separate family; inconsistency of the reproductive needs of the family with the needs of society in the simple reproduction of the population; the presence of a contradiction between the level of individual freedom of choice 
of any type of family and private relations with the level of responsibility for their behavior; the existence of a wide range of families unable to perform social functions, etc.

Kasianova (2018) determined the place of migration of citizens of Ukraine in structures of the corresponding world phenomenon through their last positioning in the system of typology of causes and forms of migration.

Lobova, S., \& Kletskova, E. (2018) identified the socio-economic causes and consequences of migration outflow of young people, which lead to a reduction in the number of able-bodied population, an increase in the demographic burden and a limitation of the reproduction potential of the population.

Soldatova, G., Shaigerova, L., Kalinenko, V. \& Kravtsova, O. (2002) considered psychological assistance to migrants.

The issue of distant families is in the field of view of the state, governmental and public organizations (La Strada-Ukraine International Women's Human Rights Center in cooperation with the Oleksandr Yaremenko Ukrainian Institute for Social Research), scientists and practitioners in socio-pedagogical and sociopsychological work. The problem of distant families where researched by: Blynova, et al (2020), Gordienko (2016), Koval'chuk A. (2012), Kuznetsova, S. A. (2013), Levchenko \& Trubavina (2007), Lyalchuk G. (2015), Malinovskaya O. (2011), Raievska (2011a), Wenger, G. (2015), and others.

Among the distant include families living at a distance due to the peculiarities of the profession (flight attendants, sailors, artists, astronauts, geologists, military, athletes); families where parents are imprisoned and serving sentences; families where the child is brought up in boarding schools.

Thus, I. Trubavina (2015) calls a distant family whose members are at a distance from each other for various reasons (profession, imprisonment, treatment, inability to support the family and transfer of children temporarily to boarding school).

The division of distant families into categories is proposed by D. Penishkevych (2005), in particular:

1) families where there is mutual understanding (each parent plays a role assigned to him, and one of them earns money for children's education, housing, starting their own business, etc.; such families cannot be called disadvantaged, social protection is reduced to providing them with social-pedagogical assistance of informative nature);

2) disadvantaged distant families (one of the parents stays at home with the children, more often - the husband; the impossibility of combining the role of mother and father in such conditions; the emergence of family members first stress, and eventually depression; often job loss due to the need for care for a child, solving the need for material resources through the migrant's earnings, alcohol abuse and neglect of the child);

3) both parents have been working abroad for a long time (the child usually remains in the care of grandparents, distant relatives, neighbors, friends, etc.; the consequence is maladaptation and social insecurity of the child).

N. Gordienko (2016) consider the reason for the formation of a distant family to be an important typological feature of the classification, namely: it was formed as a result of long-term imprisonment of one of the parents; formed after the departure of one of the parents to work abroad (as a rule, the stay of this father abroad on earnings lasts ten years or more); formed after the departure of one of the parents to a near abroad (permanent stay for seasonal work); formed as a result of the actual disintegration of the family.

Characterizing the types of distant families, we consider an important typological feature of the classification of the reason for the formation of a distant family, which is directly related to the basis of family relationships. On this basis, we distinguish the following distant families:

1) formed as a result of long-term imprisonment of one of the parents;

2) formed after the departure of one of the parents to earn money abroad (as a rule, the stay of this father abroad in earnings lasts ten years or more);

3) formed after the departure of one of the parents abroad (permanent stay for seasonal work);

4) families where parents work on a shift basis (oilmen, gasmen, etc.);

5) families in which the parents are periodically absent for a certain period of time (military, sailors, artists, athletes, etc.);

6) formed as a result of the actual disintegration of the family / husband / wife live separately from the family for a long time, which happens approximately in the following 


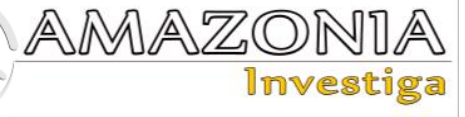

situations: a) "the scythe went on the stone" of them live with their parents, separately from the family with a child); b) one of the parents files for divorce, the other interferes with the divorce process;

7) families in which the children were born out of wedlock and the parents have never lived together;

8) families of citizens of different countries, in which the child lives periodically with one of the parents.

By the quality of family relations: prosperous and unhappy; conflict, conflict-free.

Residence by degree of kinship: families in which the child lives with one of the parents; families in which the child lives with relatives; foster family.

In the context of our study, a family without a parent who, due to the deteriorating economic situation, left the country for a certain period of time in order to find a job and provide for the family or make savings for their existence after return from abroad.

The hierarchy of motives that determine travel abroad is determined by:

- earnings to improve living conditions (buying an apartment or building a house);

- purchase of a car or other expensive durable goods;

- $\quad$ earnings to meet current life needs - food, purchase of necessary everyday goods (clothing, etc.);

- accumulation of funds to pay for children's education in higher education institutions;

- accumulation of start-up capital for starting your own business or developing your business;

- intangible motives (to see the world, to acquire certain work skills, to improve language skills, etc.).

Typical psychological features of a distant family are:

1) the absence or significant dysfunction of at least one element in the system of family relationships:

- goals (mismatch of the goals of adult family members to the purpose of the family system);

- $\quad$ the order of functioning (disorganization of family ties, which is manifested in the lack of adequate distribution of family roles, inconsistency of goals and rules in the functioning of the family as a whole system); - $\quad$ energy system (lack of activity aimed at meeting the needs of other family members, lack of focus on family development and, accordingly, unwillingness to change in the lives of each individual family member and the family as a whole);

2) low quality of family functioning up to complete non-fulfillment of family responsibilities by family members and, accordingly, dissatisfaction with their basic needs. Because the state, process and result of satisfaction or dissatisfaction of needs reflect the emotions of each person (this idea has been repeatedly emphasized by almost all researchers of emotions without exception, regardless of what theories they adhered to) can accurately judge what currently worries a person, that is, what needs and interests are relevant to him (Raievska, 2011b).

Thus, since the emotional sphere of personality is the component of the mental, which primarily responds to changes in the environment, it was suggested that the psychological discomfort of adolescents from distant families is manifested in adolescent anxiety (anxiety as a reaction to objective difficulties of a distant family), in personal problems interpersonal relationships, aggression, hostility, emotional discomfort, which affects the state of general well-being and affects their behavior.

\section{Methodology}

A structured interview was used to identify groups of adolescents from distant families; method of expert assessments, document analysis; to study the features of socio psychological adaptation and related personality traits - methods of socio - psychological adaptation (K. Rogers and R. Diamond); to study anxiety as an actual human condition and as a personality trait - a method of diagnosing selfassessment of the level of situational and personal anxiety (CHD Spielberger, YL Khanin); method "Scale of social and situational anxiety" (Kondash), method of diagnosis of school anxiety (Phillips); to determine the level of manifestation of aggression - methods of diagnosis of self-assessment of mental states (G. Eisenk), methods of diagnosis of states of aggression in adolescents (A. Bass and A. Darki); to determine the level of frustration - a method of diagnosing the level of social frustration (VV Boyko); to establish the features of the sphere of 
interpersonal relations of the child and his perception of intra-family relations - a projective method "Kinetic drawing of the family". The methods of mathematical statistics, computer data processing were used in the work, which led to their comprehensive quantitative and qualitative analysis.

When completing the task, each adolescent received individual stimulus material - texts or tasks of the test, questionnaire, which simplified the recording of answers and quantitative processing of results; diagnostic work was organized so that each student had a separate place (one at the desk), this precluded during the examination of any lack of independence or obstacles; psycho-diagnostic instruction was conducted with the whole study group (class) and met the basic experimental requirements in the field of psychology.

The study consisted of three stages. In the first stage, groups of adolescents from complete and distant families were formed and a structured interview was conducted with adolescents from distant families. In the second stage, the differences in the functioning of the emotional sphere between adolescents from complete and distant families were studied. In the third stage, gender differences in the features of the emotional sphere between the studied groups and the significance of the duration of the father or mother were analyzed.

543 children took part in the observational experiment, including 272 adolescents (130 boys, 142 girls) from complete families and 271 adolescents (139 boys, 136 girls) from distant families.

\section{Results and Discussion}

Analysis of documents and the results of a structured interview with adolescents from distant families revealed that the countries where the parents of the surveyed adolescents work were most often Italy (37\%), Greece (27\%), Russia (15\%), Spain (9\%), Poland (8\%) and Portugal (4\%). The length of stay of adolescent parents abroad is mostly uncertain.

During a structured interview, we found that in $48.37 \%$ of adolescents, the absence of one parent is one to three years (mother is absent in $23.64 \%$, father - in $24.73 \%$ ), in $51,63 \%$ of adolescents have an absence of up to one year (mother $26.9 \%$, father $-24.7 \%$ ).

It was found that the prerequisites for negative changes in the emotional sphere of adolescents from distant families and manifestations of maladaptive behavior are: lack of control over adolescent behavior by adults, lack of parental support, feelings of insecurity. The consequences are: playing games in computer clubs, being negatively influenced by the environment, alienation from the school staff, protesting against the fact that the parent has left.

An empirical study of certain indicators of the emotional sphere revealed their increase in adolescents from distant families.

In particular, the levels of anxiety were distributed as follows (pic. 1):

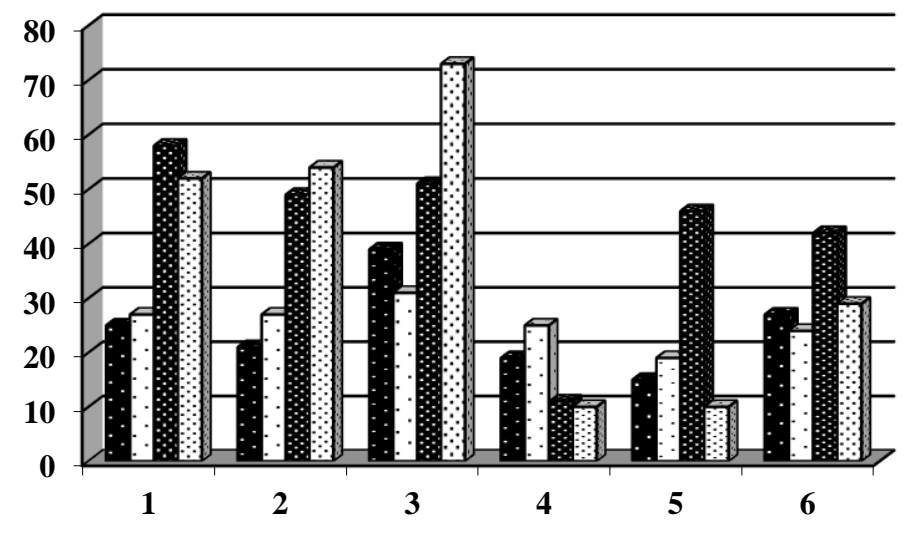

\begin{tabular}{|l|}
\hline aboys from full families \\
$\square$ girls from full families \\
$\square$ boys from distant families \\
$\square$ girls from distant families \\
\hline
\end{tabular}

Pic. 1. Differences in the increased level of anxiety of adolescents from complete and distant families (provided as a percentage of the number of adolescents from these families). 


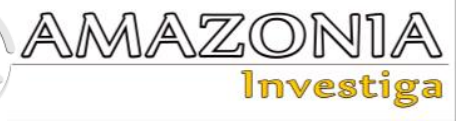

Notes:

1 - general anxiety; 2 - situational anxiety; 3 personal anxiety;

4 - school anxiety; 5 - self-esteem anxiety; 6 interpersonal anxiety

As can be seen from pic.1, increased levels of anxiety (adolescents from distant families significantly outweigh the level of adolescents from complete families. Comparison of gender differences between adolescents from distant and complete families suggested that in the absence of a father or mother responds in a special way to the personality structure of boys and girls. Girls 'anxiety is caused by the need for psychological support that parents are called to provide, boys' anxiety as a result of giving more importance to life events.

It should be noted that for girls from distant families is characterized by a high level of both situational - $17.82 \%$ and personal anxiety $52.52 \%$. Thus, girls in the absence of a father or mother tend to form states of high tension not only in situations of possible safety, but also to maintain a stable high voltage at all times. Boys from distant families show only a preparatory increase in anxiety in response to expectations of a specific threat.

The level of school anxiety was higher in adolescents from complete families (boys $5.00 \%$, girls $-10.87 \%$ ) than in adolescents from distant families (boys $-7.35 \%$, girls $-7.91 \%$ ), which is explained lack of parental control. However, the level of self-esteem (boys $33.09 \%$, girls $-7.35 \%$ ) and the level of interpersonal anxiety (boys $-30.22 \%$, girls $21.32 \%$ ) is higher than in adolescents from complete families $\left(\varphi^{*}{ }_{\mathrm{cf}}=0.911, \chi^{2}=0.540\right.$ at $\mathrm{p} \leq$ $0.05)$.

The results of the study of the level of aggression and its forms of manifestation showed that boys from distant families increase its level $-20 \%$, girls increase the level of hostility $-13.82 \%$ as a result of giving more importance to life events. Manifestations of aggression and hostility are observed in $20.86 \%$ of boys and $13.96 \%$ of girls from distant families. The level of frustration in boys $(13.82 \%)$ from distant families was significantly higher than in girls $(6 \%)$, while in complete families no significant difference was found for heterosexual groups.

According to the factors of social and psychological adaptability in boys and girls, the following indicators were identified:

maladaptation $-35.27 \%$ and $13.53 \%$, emotional discomfort $-34.55 \%$ and $26.19 \%$, escapism $29.09 \%$ and $32 \%$. This is explained by the fact that the fundamental importance for the formation of a healthy child's psyche is the awareness of being loved and protected, which is determined by the love of mother and father. If these needs are not met, the situation becomes psycho-traumatic for the child and leads to a number of negative consequences both in behavior and in the emotional sphere.

The level of intra-family relations was evidenced by the results of testing adolescents with the help of "Kinetic drawing of the family" revealed differences between groups of adolescents from complete and distant families on the following scales:

- the differences between the samples of adolescents from complete families and adolescents from distant families on the scale "Family Cohesion" are insignificant: $\varphi^{*}{ }_{\mathrm{emp}}=1.44 ; \varphi^{*}{ }_{\mathrm{cf}}=1.64(\mathrm{p} \leq 0.05), \varphi^{*}{ }_{\mathrm{emp}}<\varphi$ $*_{\mathrm{cf}}(\mathrm{p} \leq 0.07)$. That is, the cohesion of the family, as its qualitative emotional and psychological characteristics, does not depend on whether the family is complete or distant. Family cohesion will depend more on the individual psychological characteristics of its members and the characteristics of the relationship between them than on the type of family;

- differences between samples of adolescents from complete families and adolescents from distant families on the scales "Conflict in the family", "Emotional alienation in the family", "Feelings of emotional abandonment of the adolescent in the family" were recorded at the average level of significance $(\mathrm{p} \leq 0,05)$. For the final differentiation of differences, it is necessary to conduct further research, increasing the sample size and including subjects of a wider age range;

- differences between samples of adolescents from complete families and adolescents from distant families on the scale "Increased level of anxiety in adolescents" are recorded at a sufficiently high level of significance: $\varphi^{*}{ }_{\mathrm{emp}}=2.25 ; \quad \varphi^{*}{ }_{\mathrm{cf}}=1.64$ $(\mathrm{p} \leq 0.05), \varphi^{*}{ }_{\mathrm{cf}}=2.31(\mathrm{p} \leq 0.01) ; \varphi^{*}{ }_{\text {emp }}>\varphi^{*}$ cf (p $\leq \mathbf{0 . 0 1 2})$. Adolescents from distant families are significantly more anxious than adolescents from complete families;

- differences between the samples of adolescents from complete families and adolescents from distant families on the scale "Emotional well-being of the 
adolescent in the family" are recorded at a high level of significance (significant): $\varphi^{*}$ emp $=2.35(\mathrm{p} \leq 0.01) ; \varphi^{*}{ }_{\mathrm{cf}}=2.31 \quad(\mathrm{p} \leq 0.01) ;$ $\varphi *_{\text {emp }}>\varphi *_{\text {ef }}(\mathbf{p} \leq \mathbf{0 . 0 0 8})$. The level of emotional well-being of adolescents from distant families is significantly higher in complete families;

According to the results of mathematical and statistical data processing, we determined that for adolescents from distant families reliably, at a high level of significance $(\mathrm{p} \leq 0.05)$ is characterized by:

1) increased levels of anxiety compared to adolescents raised in full-fledged families; girls from distant families have a higher level of anxiety than boys from distant families; increased anxiety of adolescents in the absence of the mother for a period of one to three years; increased level of anxiety of girls in the absence of the mother up to one year;

2) increased level of aggression in boys without a mother up to one year and in boys and girls in the absence of a mother one to three years;

3) increased level of hostility in girls;

4) manifestations of maladaptation in adolescents from distant families; maladaptation in boys in the absence of the mother to one year and in boys and girls in the absence of the mother for one to three years;

5) emotional alienation from the father;

6) significantly lower levels of emotional wellbeing in adolescents raised in distant families. The level of intra-family relations affects girls in the absence of the mother for up to one year and adolescents in general in the absence of the mother for one to three years.

As a result of factor analysis, five types of groups of adolescents from distant families were identified according to the degree of emotional response with their main characteristics (pic. 2):

Type I - anxious, adapted; inherent situational and personal anxiety, feelings of emotional discomfort, guilt, resentment, sadness; absence of mother up to one and from one to three years;

Type II - aggressively anxious, maladapted; inherent situational and personal, interpersonal and self-esteem anxiety; feeling of emotional discomfort, with feelings of anger, rage, guilt; absence of mother up to one and from one to three years or father - from one to three years;

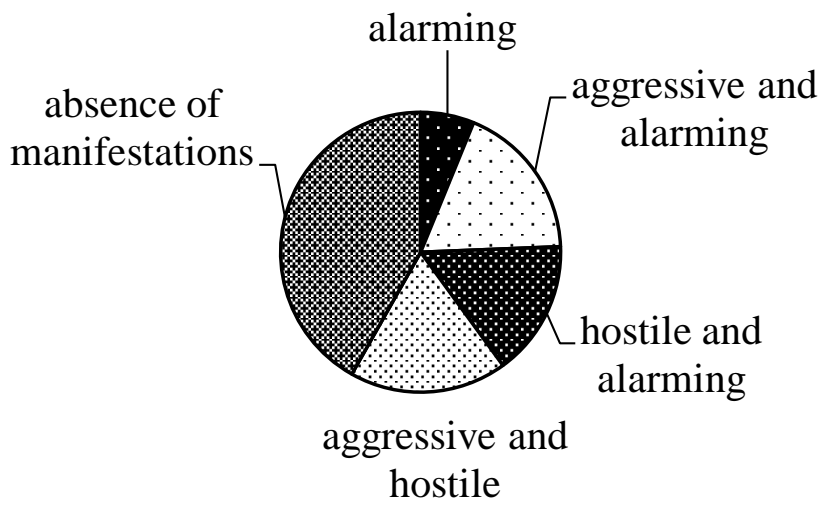

Pic. 2. Distribution of groups of adolescents from distant families according to the degree of emotional response (\%).

Type III - hostile-anxious, maladapted; inherent: situational, personal and interpersonal anxiety, self-esteem in boys; feeling of emotional discomfort with feelings of contempt, anger, guilt; absence of mother up to one and from one to three years or father - from one to three years;

Type IV - aggressively hostile, maladapted; feeling of emotional discomfort, with feelings of contempt, anger, resentment, impulsiveness; absence of mother up to one and from one to three years, father - from one to three years;
Type $V$ - no adverse effects, adapted; slight feeling of emotional discomfort; absence of a father for up to one year, for 1-3 years.

Thus, the results of empirical research have shown that negative changes in the functioning of the emotional sphere of adolescents are due to the absence of a father or mother and requires socio-psychological and legal intervention.

Analysis of changes in the emotional sphere of adolescents from distant families and the satisfaction of their basic social needs, give 


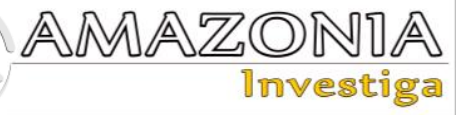

grounds to argue that the main psychological conditions of socio-psychological support of distant families are:

- establishing cooperation between penitentiary institutions, psychological services, educational institutions and distant families in the formation of harmonious relationships between parents and adolescents as a guarantee of maintaining and strengthening the mental health of the family in general and each member in particular;

- organization of special work of a school psychologist with adolescents from distant families, aimed at increasing the level of emotional well-being;

- forming a sense of family as a whole; parents awareness of their problems, her motivation to solve them in collaboration with a practical psychologist.

The definition of socio-psychological conditions made it possible to build a model of support for distant families and to identify a number of components that reveal the content of the process of harmonization of adolescents in the family (pic. 3).

The first socio-psychological component of the harmonization of adolescent relationships in the family - information, the use of professional space and new information technologies in the process of professional development and development of teachers.

The second component - preventive in order to inform teachers and parents about the problems of children from distant families, the rights and needs of children, the responsibility of parents and relatives for children, the formation of family values, responsible parenting, showing positive examples of family life, family education, resources to meet the needs of families.

The third component is diagnostic in order to study the individual characteristics of the adolescent's personality and family relationships according to the ideas of children and parents. 


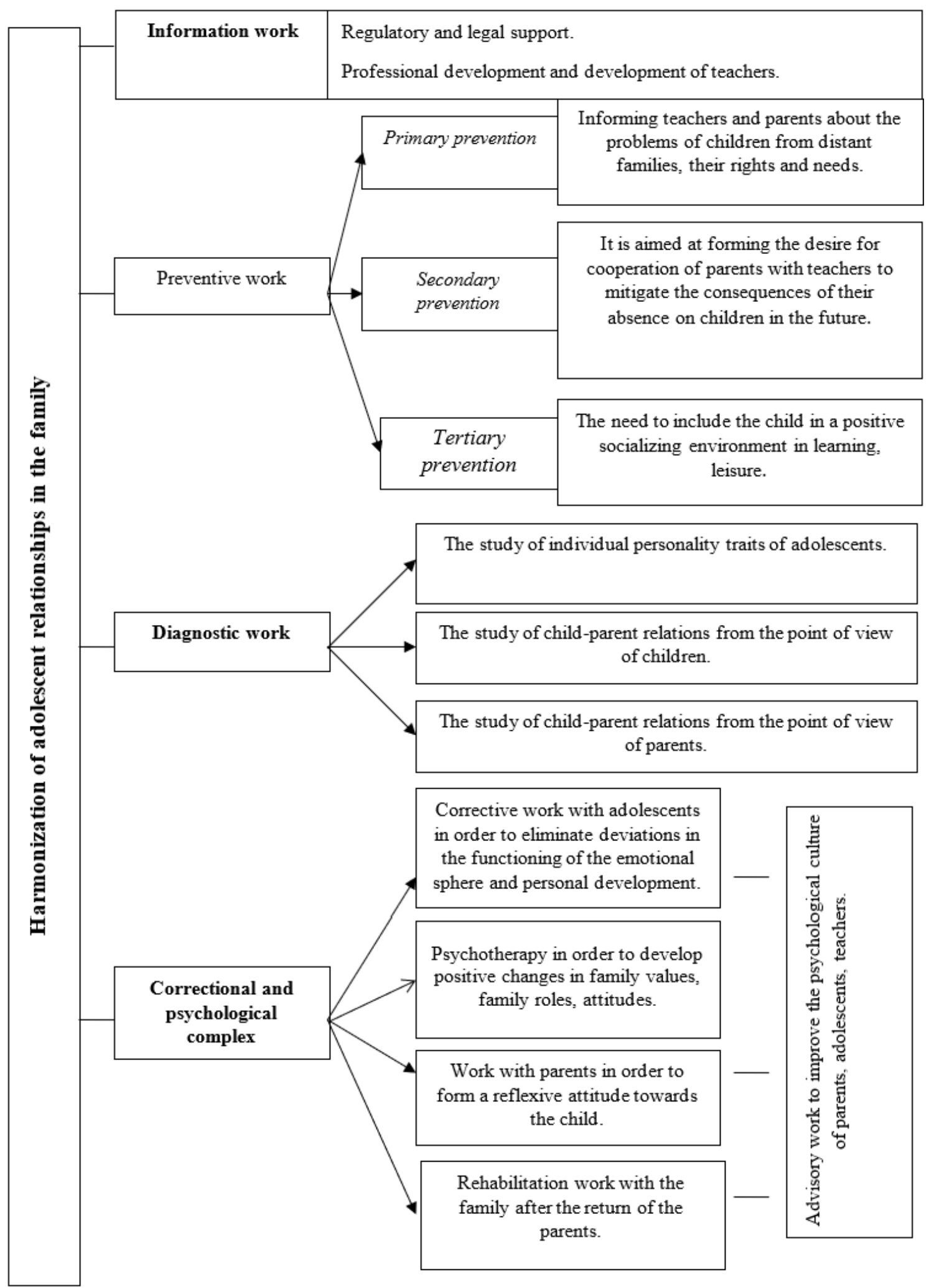

Pic. 3. Model of social and psychological support of adolescents in order to harmonize family relationships.

The fourth component is corrective in order to eliminate deviations in the functioning of the emotional sphere, cognitive, personal development and rehabilitation work with the family after the return of parents. This is the introduction of programs aimed at harmonizing the relationship of adolescents in the family. 


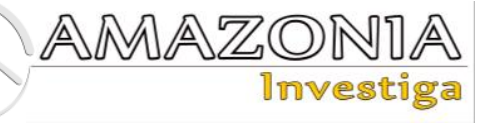

The created program consists of 8 blocks, namely: 1) communicative block - the formation of communication skills, the ability to establish contact, listen, express their point of view, argue and defend their point of view; 2) personal block - aimed at learning the inner "I" of the participants; 3) emotional block - expanding the knowledge of participants about emotions and emotional states, developing the ability to control their emotional reactions; 4) block "Removal of hostility and aggression" - the formation of adequate forms of behavior, awareness of their behavior; 5) block "Reducing the level of anxiety" - reducing emotional stress, reducing anxiety, helping to cope with their negative experiences that interfere with normal wellbeing; 6) block of social activity - to promote successful interaction of participants in various social situations, achievement of the purposes set by them; 7) family block - creating the image of the desired family; 8) the final block - the formation of a responsible attitude to their lives and health, the orientation of participants to a healthy lifestyle, the development of abilities to self-determination of their life goals and the ability to self-correction. Each block included two or three thematic classes.

Thus, the developed model of social and psychological support of distant families reflects the main trends of comprehensive overcoming of the consequences of Ukrainian labor migration in the lives of children. The correction program, which was created on the basis of the abovementioned model during the approbation, allowed to reduce the level of emotional stress, improve the general state of health and increase the level of social and psychological adaptation of adolescents from distant families. The positive dynamics of changes in the emotional sphere of adolescents, namely: reducing the level of anxiety, aggression, hostility, increasing the level of socio-psychological adaptation and improving the state of well-being and emotional well-being in the family.

\section{Conclusions}

The phenomenon of the distant family of migrant workers is a socially significant problem of our time. Long-term employment leads to a significant disruption of the system of family relations; low quality of family responsibilities by family members and, consequently, frustration with their basic needs. Typical reactions to the absence of parents, full-fledged family communication are the complexity of the process of socialization, mood disorders and mood swings, complexity, unformed self-image, gender-role identity, the dominance of addiction in behavior, impulsiveness, often manifested in deviant behavior, conflict. The most important is the problem of lack of communication with parents, their support and protection, which affects the general well-being of adolescents, causes mood swings, general well-being, increased anxiety, aggression, prone to conflict behavior in school with peers and teachers, and in a family environment.

Socio-psychological and legal situation of personal development of adolescents in a distant family makes it impossible to meet their basic material, moral and educational needs, namely: a sense of self-need; material security, stability of the family environment; unconditional acceptance of a teenager; respect for his feelings, thoughts, emotional and behavioral manifestations; positive assessment of his personality by significant adults; emotional support in case of encounter with life difficulties; mastering the skills of positive communication with others; ability to overcome obstacles in life.

Distant families of migrant workers, like every modern family, should remain the main link in the upbringing of the child: to provide him with material and psychological and pedagogical conditions for physical, moral and spiritual development. In order to properly perform its functions, a distant family needs a whole range of measures at both the regional and state levels, in particular: to provide in the Family Code for parents to grant temporary custody to other persons during their stay abroad; to organize the statistics of families of workers and childrensocial orphans for clear coordination of work with them; simplify visa barriers, which will facilitate frequent contact in families. To support children, you should use the work of psychological centers, hotlines and other social services where you can get professional help.

The prospects of further research into the phenomenon of distant families is the introduction of a structural and functional model of social and psychological support of distant families to develop programs for the correction of disharmonious emotional states of children from distant families according to certain types.

\section{Bibliographic references}

Blynova, O., Popovych, I., Semenova, N., Kashyrina, Y., Ursulenko, O., \& Kononenko, O. (2020). Personality Factors of Choosing Adaptation Strategies in a Different Cultural Environment by Labor Migrants 
from Ukraine. Amazonia Investiga, 9 (32), 45-54. Retrieved from https://doi.org/10.34069/AI/2020.32.08.5

Gordienko, N. (2016). Modern family of labor migrants as an object of social and pedagogical work in Ukraine. Pedagogical sciences, Kherson, 3, № 74, 132-136. Retrieved from https://ps.journal.kspu.edu/index.php/ps/artic le/view/2202/2008

Kasianova, M. (2018). Migration of Ukrainian Citizens to Belorussia, Moldova and Russia in the Conditions of Post-Bipolar Transformation of the International System. (Phd thesis) National Pedagogical Dragomanov University, Kyiv. Retrieved from

https://shron1.chtyvo.org.ua/Kasianova_Mar yna/Mihratsiia_hromadian_Ukrainy_do_Bil orusi_Moldovy_ta_Rosii_v_umovakh_postb ipoliarnoi_transformatsii_m.pdf

Koval'chuk A. (2012) Psychological Risks of Labour Migration. Lviv State University of Internal Affairs. Scientific Bulletin, 2 (1), 383-391. Retrieved from https://www.lvduvs.edu.ua/documents_pdf/v isnyky/nvsp/02_2012_1/12kalrtm.pdf

Kuznetsova, S. (2013). Migration attitudes as a subject of socio-psychological research. Social psychology and society, Kyiv, 4, 3445. Retrieved from https://psyjournals.ru/files/65387/spio_4_20 13.pdf

Lobova, S., \& Kletskova, E. (2018). Youth migration as a factor of detaining the regional economic development. Revista ESPACIOS, 39(34), page 32. Retrieved from: Retrieved from

https://www.revistaespacios.com/a18v39n34 /18393432.html

Logvinova, M. (2009). Civil and family-legal responsibility of parents (persons who replace them) for offenses committed by minors: a monograph. Ivano-Frankivsk: Universidad Nacional Precarpática Vasyl Stefanyk, 206 p.Retrieved from https://ua1lib.org/book/3125362/9f042e?id= $3125362 \&$ secret $=9 f 042 \mathrm{e}$

Levchenko, K., \& Trubavina I. (2007). Sociopedagogical and psychological work with children of migrant workers, International Women's Human Rights Center La Strada Ukraine, Kyiv: FOP Kupriyanova, 240 p. Retrieved from http://dspace.hnpu.edu.ua/bitstream/1234567 89/2962/1/\%D0\%A1\%D0\%BE\%D1\%86\%D $1 \% 96 \% \mathrm{D} 0 \% \mathrm{~B} 0 \% \mathrm{D} 0 \% \mathrm{BB} \% \mathrm{D} 1 \% 8 \mathrm{C} \% \mathrm{D} 0 \%$ $\mathrm{BD} \% \mathrm{D} 0 \% \mathrm{BE}-$

$\% \mathrm{D} 0 \% \mathrm{BF} \% \mathrm{D} 0 \% \mathrm{~B} 5 \% \mathrm{D} 0 \% \mathrm{~B} 4 \% \mathrm{D} 0 \% \mathrm{~B} 0 \% \mathrm{D}$
0\%B3\%D0\%BE\%D0\%B3\%D1\%96\%D1\%8 7\%D0\%BD\%D0\%B0\%20\%D1\%82\%D0\% B0\%20\%D0\%BF\%D1\%81\%D0\%B8\%D1\% $85 \% \mathrm{D} 0 \% \mathrm{BE} \% \mathrm{D} 0 \% \mathrm{BB} \% \mathrm{D} 0 \% \mathrm{BE} \% \mathrm{D} 0 \% \mathrm{~B} 3$ $\% \mathrm{D} 1 \% 96 \% \mathrm{D} 1 \% 87 \% \mathrm{D} 0 \% \mathrm{BD} \% \mathrm{D} 0 \% \mathrm{~B} 0 \% 20$ $\% \mathrm{D} 1 \% 80 \% \mathrm{D} 0 \% \mathrm{BE} \% \mathrm{D} 0 \% \mathrm{~B} 1 \% \mathrm{D} 0 \% \mathrm{BE} \% \mathrm{D}$ $1 \% 82 \% \mathrm{D} 0 \% \mathrm{~B} 0 \% 20 \% \mathrm{D} 0 \% \mathrm{~B} 7 \% 20 \% \mathrm{D} 0 \% \mathrm{~B}$ 4\%D1\%96\%D1\%82\%D1\%8C\%D0\%BC\% D0\%B8\%20\%D1\%82\%D1\%80\%D1\%83\% D0\%B4\%D0\%BE\%D0\%B2\%D0\%B8\%D1 $\% 85 \% 20 \% \mathrm{D} 0 \% \mathrm{BC} \% \mathrm{D} 1 \% 96 \% \mathrm{D} 0 \% \mathrm{~B} 3 \% \mathrm{D} 1$ $\% 80 \% \mathrm{D} 0 \% \mathrm{~B} 0 \% \mathrm{D} 0 \% \mathrm{BD} \% \mathrm{D} 1 \% 82 \% \mathrm{D} 1 \% 96$ $\%$ D0\%B2.pdf

Lyalchuk G. (2015) Features of parent-child relationships in families migrant workers. Psychological science: problems and achievements, 7, 130-145. Retrieved from http://nbuv.gov.ua/UJRN/Pnpz_2015_7_11

Malinovskaya, O. (2011) Labor migration: social consequences and response pathways. Kyiv: NISS, 40. Retrieved from https://niss.gov.ua/sites/default/files/201111/Malin_migraziya-dace3.pdf

Melnychuk, L.(2019) Modernization of public administration of social development of regions of Ukraine in conditions of decentralization. (Thesis for obtaining the doctor of sciences degree in public administration) Ukrainian State Employment Service Training Institute, Kyiv. Retrieved from https://ipk.edu.ua/wpcontent/uploads/2019/05/dis_melnychuk.pdf

Penishkevych, D. (2005). Preparing future social educators to work with distant families. Scientific Bulletin of Chernivtsi University, 225. Pedagogy and Psychology, 92-97.

Raievska, Ya. (2011a). The phenomenon of the distant family and its impact on the personality of the adolescent. Problems of modern psychology, 13, 280-290. Retrieved from http://journals.uran.ua/index.php/22276246/article/view/161001/160184

Raievska, Ya. (2011b) The phenomenon of a distant family and its impact on the team's emotional sphere. Current issues of theory and practice psychological and pedagogical training of specialists by socionomic profile, Khmelnytsky, 74-76. [PDF]. Retrieved from https://kafedrapsy.at.ua/materialy_konferencii_2011maket.pdf\#page $=74$

Soldatova, G., Shaigerova, L., Kalinenko, V. \& Kravtsova, O. (2002). Psychological assistance to migrants: trauma, cultural change, identity crisis. Moscow: Sense. Retrieved from https://bib.convdocs.org/v14614/\%D1\%81\% D0\%BE\%D0\%BB\%D0\%B4\%D0\%B0\%D1 
$\% 82 \% \mathrm{D} 0 \% \mathrm{BE} \% \mathrm{D} 0 \% \mathrm{~B} 2 \% \mathrm{D} 0 \% \mathrm{~B} 0 \_\% \mathrm{D} 0 \%$ B3.\%D1\%83._\%D0\%BF\%D1\%81\%D0\%B $8 \% \mathrm{D} 1 \% 85 \% \mathrm{D} 0 \% \mathrm{BE} \% \mathrm{D} 0 \% \mathrm{BB} \% \mathrm{D} 0 \% \mathrm{BE} \%$ D0\%B3\%D0\%B8\%D1\%87\%D0\%B5\%D1 $\% 81 \% \mathrm{D} 0 \% \mathrm{BA} \% \mathrm{D} 0 \% \mathrm{~B} 0 \% \mathrm{D} 1 \% 8 \mathrm{~F} \_\% 0 \%$ BF\%D0\%BE\%D0\%BC\%D0\%BE\%D1\%89 $\% \mathrm{D} 1 \% 8 \mathrm{C} \_\% \mathrm{D} 0 \% \mathrm{BC} \% \mathrm{D} 0 \% \mathrm{~B} 8 \% \mathrm{D} 0 \% \mathrm{~B} 3 \%$ D1\%80\%D0\%B0\%D0\%BD\%D1\%82\%D0 $\%$ B0\%D0\%BC._\%D1\%83\%D1\%87\%D0\% B5\%D0\%B1\%D0\%BD\%D0\%BE\%D0\%B5 _\%D0\%BF\%D0\%BE\%D1\%81\%D0\%BE\% D0\%B1\%D0\%B8\%D0\%B5

Trubavina, I. (2015). Problems of internally displaced persons in Ukraine as a basis for socio-pedagogical work with them. Pedagogical sciences: theory, history, innovative technologies, 8, 434-446. Retrieved from http://nbuv.gov.ua/UJRN/pednauk_2015_8_ 53

Wenger, G. (2015). A comparative analysis of the quality of family life in the traditional and distant families. Problems of Modern Psychology, Kamianets-Podilskyi, 30, 110-125. Retrieved from http://journals.uran.ua/index.php/22276246/article/view/158040/157378 